\title{
Geographic variation in ventral fluke pigmentation of humpback whale Megaptera novaeangliae populations worldwide
}

\author{
Howard C. Rosenbaum ${ }^{1,2, *}$, Phillip J. Clapham ${ }^{2}$, Judy Allen ${ }^{3}$, \\ Michlene Nicole-Jenner ${ }^{4}$, Curt Jenner ${ }^{4}$, Lilián Florez-González ${ }^{5}$, Jorge Urbán R. ${ }^{6}$, \\ Paloma Ladrón G. ${ }^{7}$, Kyoichi Mori ${ }^{8}$, Manami Yamaguchi ${ }^{9}$, C. S. Baker ${ }^{10}$ \\ ${ }^{1}$ Department of Biology, Yale University, New Haven, Connecticut 06511, USA \\ ${ }^{2}$ Center for Coastal Studies, PO Box 1036, Provincetown, Massachusetts 02657, USA \\ ${ }^{3}$ College of the Atlantic, Bar Harbor, Maine 04609, USA \\ ${ }^{4}$ Center for Whale Research, PO Box 51, Dampier, Western Australia 6713, Australia \\ ${ }^{5}$ Fundación Yubarta, A.A. 33141, Cali, Colombia \\ ${ }^{6}$ Universidad Autónoma Baja California Sur, AP Postal 19-B, CP23000, La Paz, B.C.S. 23081, Mexico \\ ${ }^{7}$ Facultad de Ciencias, Universidad Nacional Autónoma de Mexico, AP Postal 70-514, Mexico D.F., Mexico \\ ${ }^{8}$ Ogasawara Whale Watching Association, Nishimachi, Chichijima, Ogasawara, Tokyo, 100-21, Japan \\ ${ }^{9}$ Ogasawara Marine Center, Byobudani, Chichijima, Ogasawara, Tokyo, 100-21, Japan \\ ${ }^{10}$ School of Biological Sciences, University of Auckland, PO Box 92019, Auckland, New Zealand
}

\begin{abstract}
Ventral fluke patterns of humpback whales Megaptera novaeangliae were assessed to determine if pigmentation shows geographical variation across different breeding areas. Fluke photographs $(\mathrm{n}=3854)$ were collected from 7 major breeding grounds worldwide and were ranked into categories 1 (white) through 5 (black) based on the proportion of white and black pigment on the ventral surface. Average coloration varied primarily between oceanic populations, with the Southern Ocean stocks (Area IV, western Australia, and Area V, eastern Australia) characterized by significantly more light-colored flukes, while the North Pacific subpopulations consisted of individuals with significantly more dark-colored flukes. Results of statistical analyses revealed that all populations differed significantly from one another in the distribution of pigmentation classes, with the exceptions of Hawaii vs Japan, Mexico vs Japan, Mexico vs Hawaii, eastern Australia vs western Australia, and West Indies vs Colombia. Results of pigmentation analyses reveal historic and current interactions among oceanic subpopulations of humpback whales and reflect population sub-division in this species
\end{abstract}

KEY WORDS: Ventral fluke pigmentation - Zoogeography - Population ecology · Geographic variation Humpback whale Megaptera novaeangliae

\section{INTRODUCTION}

In the northern hemisphere, oceanic populations of humpback whales Megaptera novaeangliae appear to be divided into relatively discrete feeding subpopulations or 'stocks,' fidelity to which is determined matrilineally (Baker et al. 1987, Clapham \& Mayo 1987).

- Present address: Molecular Systematics Lab., American Museum of Natural History, 79th St \& Central Park West, New York, New York 10024-5192, USA; E-mail: hcr@amnh.org
These subpopulations, while largely separate during the summer, presumably interbreed on common tropical breeding grounds during the winter (Darling \& McSweeney 1985, Baker et al. 1986, Katona \& Beard 1990. Clapham et al. 1993b). In the southern hemisphere, it has been demonstrated that humpback whales feed in separate areas of the Southern Oceans and in the waters off the Antarctic Peninsula and segregate to different breeding areas (Chittleborough 1965, Mackintosh 1965). Discrete stock structure and population subdivision with little exchange are known 


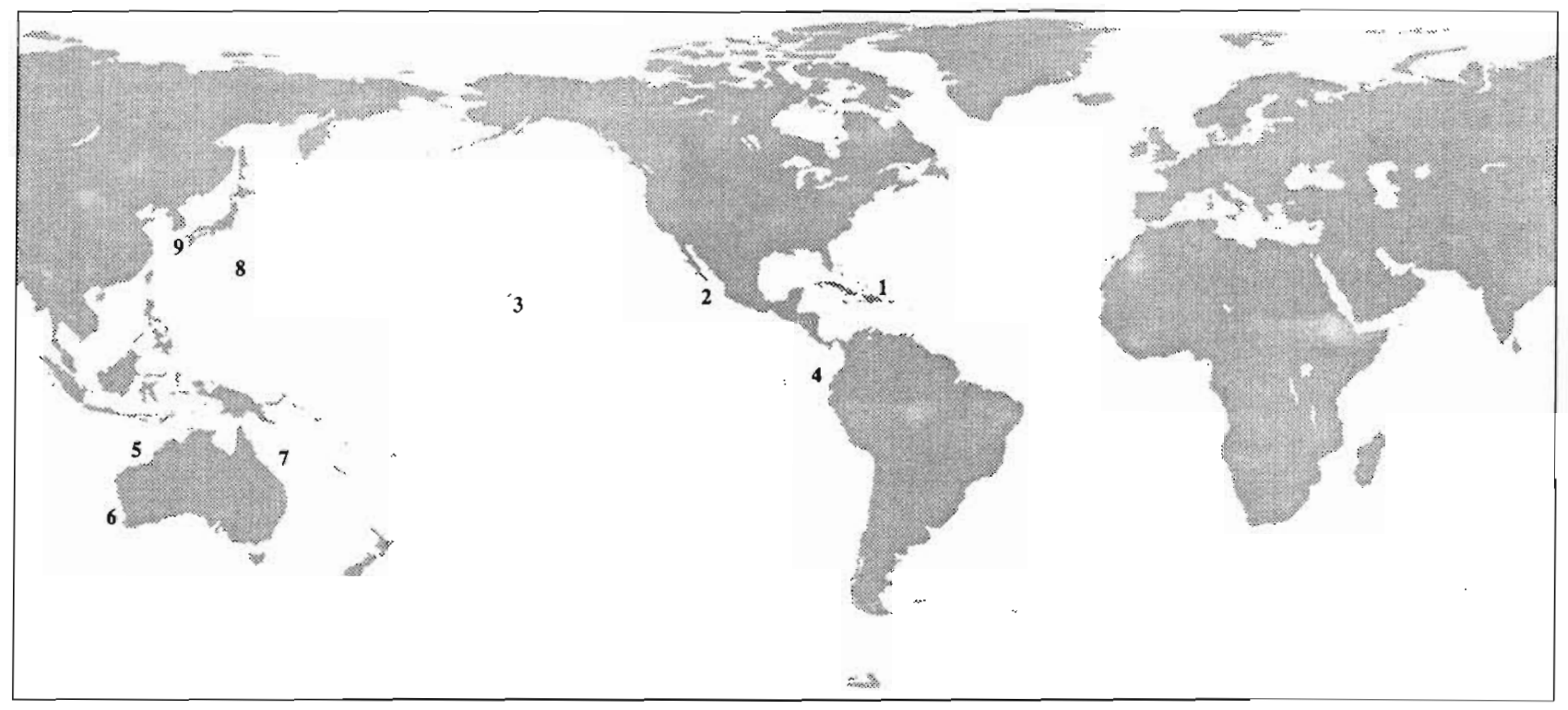

Fig. 1. Location of major humpback whale Megaptera novaeangliae breeding grounds. The numbers indicate the locales where fluke photographs were obtained for this study: (1) West Indies, (2) Pacific Coast of mainland Mexico and Baja California, (3) Hawaiian archipelago, (4) Isla Gorgona, Colombia, (5) Dampier archipelago, western Australia, (6) southern coast of western Australia, (7) eastern Australia, (8) Ogasawara (Bonin Islands), Japan, (9) Okinawa, Japan

to exist, based upon photographic identification and/or Discovery whale 'marking' showing seasonal migratory destinations and residency, in the central and eastern North Pacific (Darling \& McSweeney 1985. Baker et al. 1986, Perry et al. 1988, 1990), in the western North Atlantic (Katona \& Beard 1990, Clapham et al. 1993a) and in the Southern Oceans (South Pacific and Indian Oceans) (Chittleborough 1965, Dawbin 1966, Corkeron et al. 1994). Molecular genetic data also show significant partitioning among oceanic populations and among stocks within oceanic populations of humpback whales worldwide based upon the amount of variation detected in mitochondrial (mt) DNA haplotypes (Baker et al. 1994).

Several studies based on whaling data have documented regional differences in body or fluke coloration of humpback whales (Mathews 1937, Omura 1953. Pike 1953, Chittleborough 1965). More recent investigations of live whales have reported regional differences in pectoral fin pigmentation in the North Pacific (Herman \& Antinoja 1977, Glockner \& Venus 1983). Baker et al. (1986) found a longitudinal cline in ventral fluke pigmentation ranks of humpback whales among the stocks of the central and eastern North Pacific. In the North Atlantic, Allen et al. (1994) demonstrated that fluke coloration of humpback whales in the Gulf of Maine was significantly darker than whales from the other known feeding stocks of this population.

If the current descriptions of the population structure of this species are correct, fluke patterns of whales from individual breeding areas in both the northern hemisphere and southern hemisphere should be an amalgamation of pigmentation patterns from their respective high-latitude migratory destinations, depending on within-ocean population heterogeneity. Consequently analyses of the distribution of ventral fluke pigmentation classes should provide additional evidence for population structuring within and between oceanic populations of this species. In this study, we examine ventral fluke pigmentation patterns from 7 humpback whale breeding areas in the southern and northern hemisphere in order to assess whether geographic differences in ventral fluke pigmentation reflect suspected population subdivisions.

\section{METHODS}

Fluke photographs were obtained from 7 different breeding regions: the Hawaiian archipelago; Baja California and the Pacific coast of Mexico; Ogasawara (Bonin Islands) and Okinawa, Japan; Isla Gorgona, Colombia; the West Indies; eastern Australia; and the Dampier archipelago and southern coast of western Australia (Fig. 1). Photographs were either collected by the authors or were contributed by a variety of individuals. Unless otherwise noted, photographs from additional locales within a given region were analyzed collectively as 1 region. For example, photographs from the 'Hawaii' category are composed of whales photo- 
Table 1. Humpback whale Megaptera novaeangliae. Fluke coloration from the 7 breeding grounds in this study. Percentages are given in parentheses

\begin{tabular}{|c|c|c|c|c|c|c|c|}
\hline \multirow[t]{2}{*}{ Breeding region } & \multicolumn{5}{|c|}{ Fluke coloration number } & \multirow{2}{*}{$\begin{array}{c}\text { Total } \\
\text { (n) }\end{array}$} & \multirow{2}{*}{$\begin{array}{l}\text { Average } \\
\text { coloration }\end{array}$} \\
\hline & 1 & 2 & 3 & 4 & 5 & & \\
\hline Eastern Australia & $\begin{array}{c}186 \\
(83.0)\end{array}$ & $\begin{array}{c}30 \\
(13.4)\end{array}$ & $\begin{array}{c}6 \\
(2.70)\end{array}$ & $\begin{array}{c}2 \\
(0.90)\end{array}$ & $\begin{array}{c}0 \\
(0)\end{array}$ & 224 & 1.21 \\
\hline Western Australia & $\begin{array}{c}167 \\
(87.4)\end{array}$ & $\begin{array}{c}11 \\
(5.8)\end{array}$ & $\begin{array}{c}6 \\
(3.1)\end{array}$ & $\begin{array}{c}2 \\
(1.1)\end{array}$ & $\begin{array}{c}5 \\
(2.6)\end{array}$ & 191 & 1.26 \\
\hline Colombia & $\begin{array}{c}65 \\
(36.1)\end{array}$ & $\begin{array}{c}41 \\
(22.8)\end{array}$ & $\begin{array}{c}41 \\
(22.8)\end{array}$ & $\begin{array}{c}19 \\
(10.5)\end{array}$ & $\begin{array}{c}14 \\
(7.8)\end{array}$ & 180 & 2.31 \\
\hline West Indies & $\begin{array}{c}135 \\
(7.9)\end{array}$ & $\begin{array}{c}369 \\
(21.7)\end{array}$ & $\begin{array}{c}772 \\
(45.4)\end{array}$ & $\begin{array}{c}220 \\
(12.9)\end{array}$ & $\begin{array}{c}206 \\
(12.1)\end{array}$ & 1702 & 2.99 \\
\hline Mexico & $\begin{array}{c}61 \\
(7.7)\end{array}$ & $\begin{array}{c}110 \\
(13.8)\end{array}$ & $\begin{array}{c}155 \\
(19.5)\end{array}$ & $\begin{array}{c}185 \\
(23.2)\end{array}$ & $\begin{array}{c}285 \\
(35.8)\end{array}$ & 796 & 3.65 \\
\hline Hawaii & $\begin{array}{c}52 \\
(8.9)\end{array}$ & $\begin{array}{c}43 \\
(7.4)\end{array}$ & $\begin{array}{c}109 \\
(18.7)\end{array}$ & $\begin{array}{c}127 \\
(21.8)\end{array}$ & $\begin{array}{c}252 \\
(43.2)\end{array}$ & 583 & 3.83 \\
\hline Japan & $\begin{array}{c}9 \\
(5.1)\end{array}$ & $\begin{array}{c}14 \\
(7.9)\end{array}$ & $\begin{array}{c}28 \\
(15.7)\end{array}$ & $\begin{array}{c}41 \\
(23.0)\end{array}$ & $\begin{array}{c}86 \\
(48.3)\end{array}$ & 178 & 4.02 \\
\hline
\end{tabular}

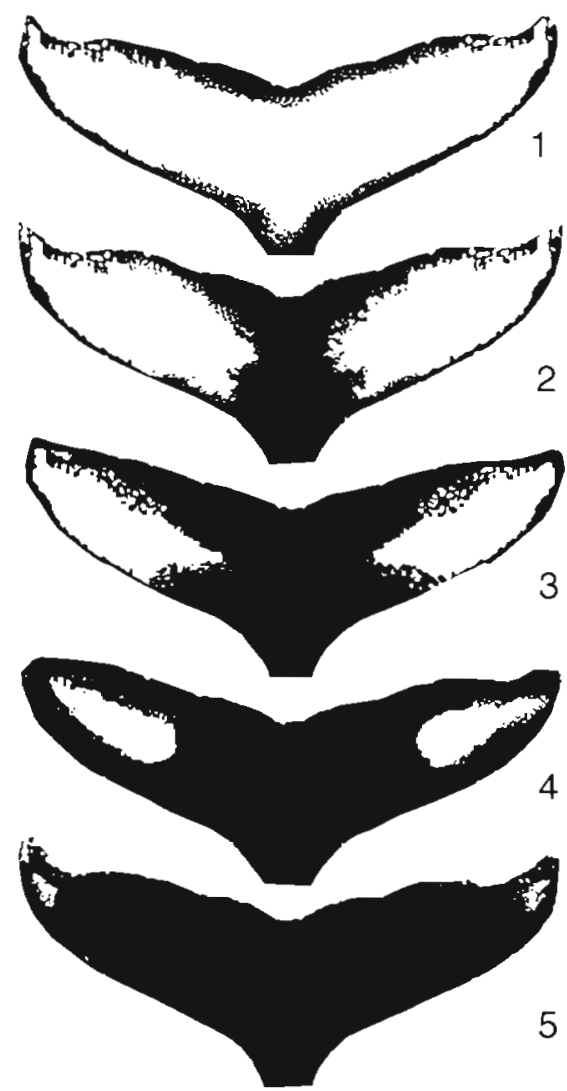

Fig. 2. Megaptera novaeangliae. Examples of ventral fluke pigmentation ranks of humpback whales. Photographs showing the whole ventral flukes were ranked in accordance with the 1 to 5 scale shown above based on the proportion of black and white pigmentation graphed at different locations throughout the Hawaiian archipelago. Photographs selected for analysis showed the whole ventral fluke with photographic quality rated at good or excellent using the system described by Katona \& Beard (1990). Fluke photographs were then assessed by eye and assigned rank values on a 1 to 5 , white to black scale, based on the proportion of white and black coloration present on the flukes; examples are shown in Fig. 2. This method of numerically categorizing ventral fluke patterns is currently used by field scientists and by curators of fluke photographs. Whales photographed in a given area more than once were ranked only once. The distribution of pigmentation classes among breeding aggregations was analyzed using the nonparametric KruskalWallis for tied ranks and nonparametric NewmanKeuls test statistics, both of which utilize rank ordering (Zar 1974). Multiple pairwise comparisons were corrected using Bonferroni's approach $\left(\mathrm{p}_{\alpha}=\alpha_{0.05} / \mathrm{N}\right)$ where the corrected significance level for multiple pairwise comparisons $\left(\mathrm{p}_{\alpha}\right)$ is equal to the $95 \%$ confidence interval divided by the total number of multiple comparisons (N) (Johnson \& Wichern 1992).

\section{RESULTS}

Photographs from a total of 3854 individual humpback whales were analyzed in this study. Fluke pigmentation by rank for each of the 7 breeding grounds is shown in Table 1. Average fluke coloration (the arithmetic mean for each area's sample) was most black for Japan (mean $=4.02$ ) decreasing in average 
rank from Hawaii, Mexico, the West Indies, and Colombia. The whitest average fluke coloration was found at western Australia (WA) and eastern Australia (EA) at 1.26 and 1.21, respectively (Table 1). Fluke pigmentation differed significantly among the 7 breeding areas (Kruskal-Wallis statistic $=1173.57$, $\mathrm{df}=6, \mathrm{p}<$ $0.001)$. Fig. 3 shows percentage of ranks for the 7

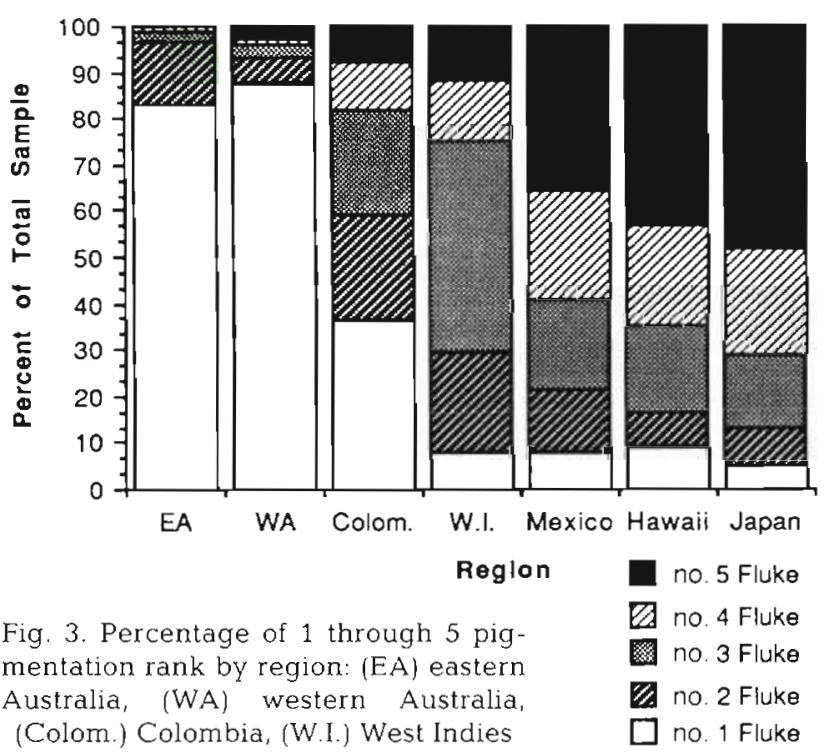

regions. Approximately 83 to $87 \%$ of the EA and WA whales photographed had no. 1 ranked flukes; in the North Pacific, between 36 and $48 \%$ of the whales photographed from Mexico. Hawaii and Japan had no. 5 flukes, with 21 to $23 \%$ of whales in the no. 4 category as well. The West Indies sample was dominated by individuals with a no. 3 rank.

Multiple pairwise comparisons using the nonparametric Newman-Keuls test revealed that all populations differed significantly in ventral fluke pigmentation from each other with the exception of the following pairwise comparisons: Japan vs Hawaii, Mexico vs Hawaii, Mexico vs Japan, eastern Australia vs western Australia, and the West Indies vs Colombia (Table 2).

\section{DISCUSSION}

Previous studies have revealed differences in pigmentation among stocks of humpback whales within the North Pacific (Baker et al. 1986), the North Atlantic (Allen et al. 1994), and the Southern and Indian Oceans (Chittleborough 1965). This study demonstrates significant differences in ventral fluke pigmentation between worldwide interoceanic breeding stocks of humpback whales. The Southern Oceans' stocks analyzed in this study had higher frequencies of

Table 2. Multiple pairwise comparisons by nonparametric Newman-Keuls test. Pairwise comparisons of breeding ground regions are listed below. $R_{B}-R_{A}$ is the difference in ranks between 2 populations being compared. Standard error (SE) and test statistic (q) values are presented below. Significant differences between populations are determined using the Bonferroni confidence interval for multiple pairwise comparisons, where $p_{\alpha}=0.0024$ from $p_{\alpha}=\alpha_{0.05} / \mathrm{N}$ ( $\mathrm{N}=$ total number of pairwise comparisons). S: statistical significance exists between populations; NS: no significant differences detected in ventral fluke pigmentation ranks between populations. EA: eastern Australia; WA: western Australia

\begin{tabular}{|c|c|c|c|c|}
\hline Comparisons & $R_{B}-R_{A}$ & $\mathrm{SE}$ & $q$ & Significance \\
\hline Japan vs EA & 2180.9 & 82.5 & 26.4 & $\mathrm{~S}$ \\
\hline Japan vs WA & 2138.6 & 94.4 & 22.7 & $\mathrm{~S}$ \\
\hline Japan vs Colombia & 834.56 & 90.4 & 9.2 & $\mathrm{~S}$ \\
\hline Japan vs West Indies & 821.6 & 91.11 & 9.1 & $\mathrm{~S}$ \\
\hline Japan vs Mexico & 286.9 & 59.9 & 4.8 & NS \\
\hline Japan vs Hawaii & 14.5 .3 & 53.4 & 2.7 & NS \\
\hline Hawaii vs EA & 2035.6 & 84.0 & 24.2 & S \\
\hline Hawaii vs WA & 1993.3 & 95.7 & 20.8 & $\mathrm{~S}$ \\
\hline Hawaii vs Colombia & 1201.04 & 91.8 & 13.1 & $\mathrm{~S}$ \\
\hline Hawaii vs West Indies & 676.3 & 92.4 & 7.3 & $S$ \\
\hline Hawaii vs Mexico & 141.6 & 60.9 & 2.3 & NS \\
\hline Mexico vs EA & 1894.0 & 87.6 & 21.6 & $\mathrm{~S}$ \\
\hline Mexico vs WA & 1851.7 & 98.3 & 18.8 & $\mathrm{~S}$ \\
\hline Mexico vs Colombia & 1059.44 & 91.8 & 11.5 & $S$ \\
\hline Mexico vs West Indies & 534.7 & 95.1 & 5.6 & $\mathrm{~S}$ \\
\hline West Indies vs EA & 1359.3 & 111.3 & 12.2 & $\mathrm{~S}$ \\
\hline West Indies vs WA & 1317.0 & 120.4 & 10.9 & $\mathrm{~S}$ \\
\hline West Indies vs Colombia & 524.74 & 117.0 & 4.48 & NS \\
\hline Colombia vs EA & 834.5 & 111.3 & 7.5 & $\mathrm{~S}$ \\
\hline Colombia vs WA & 792.3 & 120.4 & 6.6 & $\mathrm{~S}$ \\
\hline EA vs WA & 42.3 & 114.6 & 0.37 & NS \\
\hline
\end{tabular}


lighter pigmented flukes, while the North Pacific stocks (Japan, Hawaii, and Mexico) were characterized by higher frequencies of whales with no. 4 and no. 5 ranks. The West Indies and Colombia populations were similar in their distribution of pigmentation categories. The similarities in ventral fluke pigmentation between these 2 interoceanic populations are most likely not indicative of panmixy, but result from chance effects inherent in the phenotype.

Genetic variation of mtDNA haplotypes is partitioned among oceanic populations of humpback whales in the North Pacific, western North Atlantic, and Southern Oceans (Baker et al. 1994); in the present study, significant differences exist in the distribution of ventral fluke pigmentation classes among the North Pacific, Equatorial Pacific (Colombia), western North Atlantic (West Indies), and Southern Ocean populations of humpback whales. Comparisons of results from molecular studies with those presented here are difficult, since the analyses of ventral fluke pigmentation do not permit determination of exact phylogenetic relationships. Since most populations contain individuals with all 5 pigmentation classes and occasionally the difference between adjacent classes is a subtle distinction, this phenotype is more analogous to a trait rather than to a character state. Given the robustness of the current dataset, however, this phenotype can be used to detect differences at the individual and population levels.

\section{North Pacific}

Recent study suggests that more segregation exists within the central and eastern North Pacific than in the North Atlantic, where whales from separate feeding areas mix on a common breeding ground. Humpback whales that feed off central California predominantly breed off Baja California and the Pacific coast of Mexico (Baker et al. 1986, Calambokidis et al. 1990, Perry et al. 1990), while whales that feed further northwest, from southeastern Alaska through the western Gulf of Alaska, primarily migrate during the breeding season to the waters surrounding the Hawaiian islands. Perry et al. (1990) and Calambokidis et al. (1990) propose that there is incomplete separation between the feeding herds of Alaska and California on the breeding grounds. Gene flow between these 2 stocks is directly evident from recent photo-identification and molecular data; Medrano (1993) and Baker et al. (1994) found the dominant haplotype among whales sampled off Hawaii to be common among whales sampled in Mexican waters

Previous work on pigmentation differences generally supports this concept of population structure in the North Pacific. According to Baker et al. (1986), there were no significant coloration differences between whales photographed off Hawaii and off Mexico, although the sample size for the latter was small (36 individuals), and came primarily from a single location, the Islas de Revillagigedo (Socorro Islands). The results of the present study are consistent with the findings of Baker et al. (1986) despite the more liberal 3 category classification used by those authors, or the increased and more representative sample size collected off Mexico in subsequent years (Urbán \& Aguayo 1987). No significant differences in coloration between Hawaiian and Mexican whales, as suggested by the pairwise comparisons, supports the theory of incomplete separation of feeding stocks on the breeding grounds. Our results along with existing genetic and movement data strongly suggest that belief in limited exchange between these 2 regions is justified.

The relationship between the stocks of the western and central North Pacific still remains unclear. Humpback whales were thought to be divided into 2 stocks in the North Pacific based upon 19th century whaling data: an 'Asian' stock that winters in the waters south of Japan and an 'American' stock that migrates along the west coast of North America to breeding areas off Mexico and feeding areas off Alaska (Kellog 1929). It was later suggested that whales that winter in Hawaii were part of the 'American' stock (Rice 1974). In this study we found no significant variation between the rankings of the samples from Hawail and Japan, nor between Mexico and Japan. Darling \& McSweeney (1985), as well as Baker et al. (1986) suggest that exchange between Hawail and Japan could occur through the westernmost feeding regions of Alaska. Furthermore, 3 photographic matches have been made between Hawaii and Japan, indicating that gene flow can occur between these populations (Darling \& Cerchio 1993); no photographic matches have been found between Mexico and Japan. The lack of significant differences in ventral fluke pigmentation among these interoceanic stocks supports this theory of exchange between these areas, although the sample size from Japan is small in comparison to that of Hawaii and Mexico. Genetic results should provide a more accurate description of the population structure of these 2 regions as will further results and photographs from breeding areas of Japan.

\section{Equatorial Pacific}

According to Stone et al. (1990), whales photographed off the Pacific coast of Colombia feed off the Antarctic Peninsula (the whaling management area known traditionally as Antarctic Area I), but it has also been suggested that whales from the North Pacific 
may migrate further south (past Mexico or Hawaii) to the breeding grounds of Central and South America, including Colombia (Stone et al. 1990, Steiger et al. 1991). Evidence of limited trans-equatorial gene flow is demonstrated by 2 haplotypes from the North Pacific stocks that are most parsimoniously derived from the ancestral Southern Ocean haplotype (Baker et al. 1994). The significant differences in distribution of pigmentation ranks between Colombian humpbacks and all other areas in the present study are indicative of a lack of significant exchange between the Mexican and Colombian breeding grounds. Furthermore, the results suggest that whales photographed off eastern or western Australia and Colombia show fidelity to different feeding regions in the Antarctic. Additional work is required to identify the relationship between whales photographed off either Colombia or the Antarctic Peninsula and those observed in the Abrolhos Banks, Brazil ( $n=48$ ). To date, no photographic match has been documented between Brazil and the Antarctic or between Colombia and Brazil.

\section{Southern Oceans}

In the South Pacific and Indian Oceans, Chittleborough (1965), using a 1 to 4 classification scheme, found that there were significant differences in ventral and lateral body coloration between Area IV (western Australia) and Area V (eastern Australia) stocks; based on these differences and on Discovery whale 'mark' recovery, he concluded that eastern and western Australia represented distinct populations and that little if any mixing occurred between them. However, Chittleborough (1965) also found that $10 \%$ of the whales marked in Area $\mathrm{V}$ had been recaptured in Area IV. Furthermore, Baker et al. (1994) found that there is significant genetic distance between the Area IV and V stocks, although 2 of the 3 most common haplotypes in the Southern Oceans are found in both eastern and western Australia.

In contrast, the results presented here indicate that the 2 populations do not differ significantly in average pigmentation ranking nor in the distribution of classes of pigmentation. The lack of concordance between the coloration and molecular data may also result from the resolution offered by each type of analysis, as well as by differences in evolutionary time scales over which expressed (phenotypic) traits and neutral genetic characters accumulate changes.

\section{Biases}

Sampling bias could have affected results from any of the breeding regions. In the central and eastern
North Pacific and in the western North Atlantic, it has been shown that males, on average, have lighter fluke coloration than females (Baker 1985, Allen et al. 1994). In the breeding areas, high percentages of samples in some years may have been obtained from competitive groups that are known to be primarily composed of males (Clapham et al. 1992). This sex-related sampling bias could explain the lighter coloration ranks than expected for any of the breeding areas if sampling effort was stratified and not consistent across all locales. Given the sample sizes in this study and that competitive group individuals will represent only a fraction of the total sample, it is unlikely that sexual dichromism in this species would significantly affect the findings.

\section{SUMMARY}

The significant differences in ventral fluke pigmentation among the worldwide breeding populations of humpback whales reported here provides an improved description of oceanic structuring among stocks of this species; variation detected in this phenotype reflects current molecular findings regarding the population structure of humpback whale stocks worldwide. Similarities in the distribution of pigmentation classes among stocks may also be indicative of gene flow between intra-oceanic subpopulations.

Acknowledgements. We thank Dr Ernest Williams and Dr Junhyong Kim for valuable advice concerning statistical analyses. We thank the following persons and organizations for assistance during field collection or contribution of photographs: in eastern Australia: Gordon Anderson, M. M. Bryden, Miranda Brown, P. J. Corkeron, and Rob Slade; in western Australia: John Bannister, the Western Australian Museum, and Chris Burton; in the North Pacific: L. Medrano G., Mario Salinas Z., Anelio Aguayo, Lorenzo Rojas; in Japan: Jim Darling, Shigeki Komori, The Worldwide Fund for Nature-Japan, Hiroyuki Suganuma, The Ogasawara Marine Center, The Ogasawara Whale Watching Association; in Colombia: Juan Capella, Ignacio Barraquer, Fundación Yubarta, and COLCIENCIAS; in the West Indies: David Mattila, the Center for Coastal Studies, College of the Atlantic, CIBIMA, and Osvaldo Vasquez. Rob DeSalle and Rob Dorit provided insightful comments on earlier versions of this manuscript, as did 3 anonymous reviewers. This work was funded by a Thomas J. Watson Fellowship to H.C.R. Additional generous support was provided by WWF Japan, the government of Western Australia, Patagonia Products, Pelican Products and a grant from the IWC to C.S.B.

\section{LITERATURE CITED}

Allen J, Rosenbaum HC, Katona SK, Clapham PJ, Mattila DK (1994) Regional and sexual differences in fluke pigmentation of humpback whales (Megaptera novaeangliae) from the North Atlantic Ocean. Can J Zool 72:274-279 
Baker CS (1985) The population structure and social organization of humpback whales (Megaptera novaeangliae) in the central and eastern North Pacific. PhD dissertation, University Microfilms International, Ann Arbor

Baker CS, Perry A, Herman LM (1987) Reproductive histories of female humpback whales (Megaptera novaeangliae) in the North Pacific. Mar Ecol Prog Ser 41:103-114

Baker CS, Herman LM, Perry A, Lawton WS, Straley JM, Wolman AA, Kaufman GD, Winn HE, Hall JD, Reinke JM, Ostman J (1986) Migratory movement and population structure of humpback whales (Megaptera novaeangliae) in the central and eastern North Pacific. Mar Ecol Prog Ser 31:105-119

Baker CS, Slade RW, Bannister JL, Abernathy RB, Weinrich MT, Lien J, Urbán J, Corkeron P, Calambokidis J, Vasquez O. Palumbi SR (1994) Hierarchical structure of mitochondrial DNA gene flow among humpback whales Megaptera novaeangliae, world-wide. Mol Ecol 3: $313-327$

Calambokidis J, Cubbage JC, Steiger GH, Balcomb $\mathrm{KC}_{1}$ Bloedel P (1990) Population estimates of humpback whales in the Gulf of the Farallones. In: Hammond PS, Mizroch SA, Donovan GP (eds) Individual recognition of cetaceans: use of photo-identification and other techniques to estimate population parameters. Rep Int Whal Comm Spec Issue 12:325-334

Chittleborough RG (1965) Dynamics of two populations of humpback whales, Megaptera nodosa (Bonnaterre). Aust J mar Freshwat Res 16:33-128

Clapham PJ, Mayo CA (1987) Reproduction and recruitment in individually identified humpback whales (Megaptera novaeangliae) observed in Massachusetts Bay: 19791985. Can J Zool 65:2853-2863

Clapham PJ, Baraff LS, Carlson CA, Christian MA, Mattila DK, Mayo CA, Murphy MA, Pittman S (1993a) Seasonal occurrence and annual return of humpback whales (Megaptera novaeangliae) in the southern Gulf of Maine. Can J Zool 7 1:440-443

Clapham PJ, Palsboll PJ, Mattila DK (1993b) High-latitude composition of humpback whale (Megaptera novaeangliae) competitive groups in Samana Bay: further evidence for panmixis in the North Atlantic population. Can J Zool 71:1065-1066

Clapham PJ, Palsboll PJ, Mattila DK, Vasquez O (1992) Composition and dynamics of humpback whale competitive groups in the West Indies. Behavior 122:182-194

Corkeron PJ, Brown MR, Slade RW, Bryden MM (1994) Humpback whales Megaptera novaeangliae (Cetacea: Balaenopteridae) in Hervey Bay, Queensland. Wildl Res 21:293-305

Darling JD, McSweeney DJ (1985) Observations on the migrations of North Pacific humpback whales (Megaptera novaeangliae). Can J Zool 63:308-314

Darling J, Cerchio S (1993) Movement of a humpback whale, Megaptera novaeangliae, between Japan and Hawaii. Mar Mamm Sci 9(1):84-89

This article was submitted to the editor
Dawbin WH (1966) The seasonal migratory cycle of humpback whales. In: Norris KS (ed) Whales, dolphins and porpoises. University of California Press, Berkeley, p 145-170

Glockner DA, Venus SC (1983) Identification, growth rate, and behavior of humpback whales (Megaptera novaeangliae) cows and calves in the waters off Maui, Hawaii, 1977-1979. In: Payne R (ed) Behavior and communications of whales. AAAS Sel Symp 76:447-464

Herman LM, Antinoja RC (1977) Humpback whales in the Hawaiian breeding waters: population and pod characteristics. Sci Rep Whales Res Inst 29:59 - 85

Johnson RA, Wichern DN (1992) Applied multivariate statistical analysis. Prentice-Hall, Englewood Cliffs, NJ

Katona SK, Beard JA (1990) Population size, migration and substock structure of the humpback whale (Megaptera novaeangliae) in the western North Atlantic ocean. In: Hammond PS, Mizroch SA, Donovan GP (eds) Individual recognition of cetaceans: use of photo-identification and other techniques to estimate population parameters. Rep Int Whal Comm Spec Issue 12:325-334

Kellog R (1929) What is known of the migration of some of the whalebone whales. Smithson Inst Annu Rep 1928:467-494

Mackintosh NA (1965) The stocks of whales. Fishing News (Books) Ltd, London

Mathews LH (1937) The humpback whale, Megaptera nodosa. 'Discovery' Rep 17:7-92

Medrano L (1993) Estudio genetico del rorcual jorobado en el Pacifico mexicano. Doctoral thesis, Facultad de Ciencias Universidad Nacional de Mexico, Mexico DF

Omura H (1953) Biological study on humpback whales in the Antarctic whaling areas IV and V. Sci Rep Whales Res Inst, Tokyo 8:81-102

Perry A, Baker CS, Herman LM (1990) Population characteristics of individually identified humpback whales in the central and eastern North Pacific: a summary and critique. In: Hammond PS, Mizroch SA, Donovan GP (eds) Individual recognition of cetaceans: use of photo-identification and other techniques to estimate population parameters. Rep Int Whal Comm Spec Issue 12:325-334

Perry A, Baker CS, Mobley J, Herman LM (1988) Catalogue of North Pacific humpback whales. Sea Grant, Hawaii

Pike GC (1953) Colour pattern of the humpback whales from the coast of British Columbia. J Fish Res Bd Can 171:1-54

Rice DW (1974) Whales and whale research in the eastern North Pacific. In: Schevill WE (ed) The whale problem. Harvard University Press, Cambridge, p 218-238

Steiger GH, Calambokidis J, Sears R, Balcomb KC, Cubbage JC (1991) Movements of humpback whales between California and Costa Rica. Mar Mamm Sci 7:306-310

Stone G, Flórez González L, Katona SK (1990) Whale migration record. Nature 346:705

Urbán RJ, Aguayo AL (1987) Spatial and seasonal distribution of the humpback whale, Megaptera novaeangliae, in the Mexican Pacific. Mar Mamm Sci 3:333-344

Zar JH (1974) Biostatistical analysis. Prentice-Hall, Englewood Cliffs, NJ

Manuscript first received: August 30, 1994 Revised version accepted: March 15, 1995 